Pounden, W. D. \& Hibbs, J. W. (1950). F. Dairy Sci. 33, 639.

Preston, T. R. (1957). N.A.A.S. Quart. Rev, no. 35, p. 18.

Sugden, B. (1953). F. gen. Microbiol. 9, 44.

Weller, R. A. (1957). Aust. F. biol. Sci. 10, 384 .

\title{
The treatment and prevention of bloat with anti-foaming agents
}

\author{
By C. S. W. ReID*, Plant Chemistry Division, D.S.I.R., \\ Palmerston North, New Zealand
}

Excessive frothing of the rumen contents during fermentation interferes with the normal elimination of gas. The effect appears to be due partly to its being trapped in a stable foam and partly to a direct inhibitory action of foam on eructation. There is strong evidence that acute pasture bloat is caused in this manner (for reviews, see Cole, Dougherty, Huffman, Hungate, Kleiber \& Maclay, I956; Johns, I956, 1958). The foaming agents in this instance appear to be the plant cytoplasmic proteins, possibly assisted by salivary mucoprotein (Mangan, 1959), and saponins and particulate matter may act as stabilizers.

A certain amount of foam is usually present in the rumen. Bloating is therefore a matter of degree; but why the change from mild to excessive foaming takes place is not yet fully understood. Further, although foaming may initiate the disorder, in the later stages secondary complications may occur, presumably originating as physiological reactions of the animal to inflation of the rumen.

If bloat is the consequencc of foaming, the administration of anti-foaming agents should be effective in both treatment and prevention. This paper reviews work carried out in New Zealand on the use of these substances in the treatment and prevention of acute bloat in grazing dairy cattle.

\section{Treatment}

Administration of anti-foaming agents was the only consistently useful treatment found (Johns, 1954; Reid \& Johns, I957 and unpublished results). A wide variety of fats and oils, as well as certain detergents and other synthetic surface-active substances, were effective, but some detergents were almost valueless, and all silicone preparations were unreliable.

After administration of an anti-foaming agent to a bloated animal, there may be little immediate effect, then deflation occurs over a relatively short time. This apparent latent period, which is quite variable, is important because it represents a substantial proportion of the time taken to give relief. Its cause is not yet known, but three possibilities are: variations in the strength of the foam; the rate of dispersion of the agent through the ingesta; or the necessity to clear a particular region, presumably the cardia. Dispersion would certainly offer some difficulty, since the foam is not usually in a discrete layer or block, but intimately mixed through the

\footnotetext{
* Present address: Physiological Laboratory, University of Cambridge.
} 
rumen contents. Search for more rapidly acting agents than the oils has so far proved rather disappointing. A detergent, Pluronic L62 (Wyandotte Chemicals Corporation, Wyandotte, Mich., U.S.A.), is the most promising material.

Choice of an agent for field use must take into consideration not only effectiveness, but also possible effects on the health of animals or the quality of their milk, and the cost. Investigations have therefore been made into the effects of mineral oils on appetite (Reid, I957) and on the absorption of dietary fat-soluble materials (see below), the effects of treatments on the rumen microbiota, and the effects of administration of various common fats on the production and quality of milk and butterfat (McDowall, Patchell \& Reid, I957; McDowall, Reid \& Patchell, I957).

Perhaps the most interesting finding was that ingestion of paraffin, as with nonruminants, reduced the absorption of carotene and vitamin $\mathrm{E}$. This effect was reflected by lowered concentrations of carotene, vitamin $\mathrm{A}$ ester and vitamin $\mathrm{E}$ in the blood, and of carotene and vitamin $\mathrm{E}$ in the milk (McDowall, McGillivray \& Reid, I957; McGillivray, McDowall \& Reid, 1959). The effect was proportional to the dose rate (McGillivray, 1957). Vitamin $\mathrm{K}$ absorption did not appear to be significantly affected (Reid \& Hutchings, I959).

At present, emulsified ruminant tallow and arachis oil are considered the most acceptable agents. The dose is about $120-150 \mathrm{~g}$ fat.

\section{Prevention}

It was quickly discovered that anti-foaming agents could be used prophylactically (Johns, r954; Reid, I955; Reid \& Johns, r957). A small amount of oil, say $50 \mathrm{ml}$, given before feeding, would allow a hungry animal to fill itself with dangerous clover without obvious adverse effect. This protection was short, however, lasting only some $2 \mathrm{~h}$.

The problem in turning this protection to practical use lay in the maintenance of effective concentrations of anti-foaming agent in an environment that changes continually as feed, saliva and water enter and digesta leave. The rate of loss of oils from the rumen appeared to be high, and uneconomically large amounts were required to protect an animal from milking to milking. The alternative was to administer smaller amounts at shorter intervals, which could be achieved by adding the agent to the drinking water, or by applying it directly on to the feed.

Because the drinking pattern is affected by so many factors (see Leitch \& Thomson, I944-5; Winchester \& Morris, 1956; Campbell \& Munford, 1957), treatment of the drinking water was considered unlikely to be fully reliable. In field trials, it was found to reduce, but not to eliminate, bloat; similar results were obtained in experiments in Australia (Southcott \& Hewetson, 1958) and the United States (Brown, Johnson, Jacobson \& Homeyer, I958).

The simplest way of applying an anti-foaming agent to the feed is by spraying. In what proved the most satisfactory variant of the procedure, the day's ration of pasture is sprayed evenly with an emulsion of arachis oil or tallow at the rate of $90-180 \mathrm{~g} \mathrm{fat} / \mathrm{cow} /$ day. The sprayed area is grazed in about three breaks, the animals 
being kept off unsprayed pasture by means of electric fences. The principal advantages of this system are that, since the animals are always grazing sprayed pasture, they have no option but to ingest the anti-foaming agent, and that the agent enters the rumen in the most advantageous manner-intimately mixed with the dangerous herbage (Reid, I955, 1958).

Pasture spraying is considered to be a practical control measure and has been in use on New Zealand farms for the past four seasons. It has been particularly successful on irrigated pastures in Australia (Geddes (quoted by Johns, I956); Flynn, I958).

\section{Dietary anti-foaming agents and bloat}

The quantity of oil required to protect grazing cows by pasture spraying is rather less than the quantity of crude lipids taken in the diet, some 300-600 g a day for lactating animals. Since these plant lipids have good foam-breaking properties in vitro (Mangan, 1959), the possibility arises that variations in the proportions of foaming and anti-foaming agents, or in the 'availability' of the anti-foaming agents within the rumen might be factors in the aetiology of bloat. Some observations have been made on various aspects of the lipid intake of cows feeding on red clover.

The plant. The average crude lipid content of red-clover herbage was $4-5 \%$ of the dry matter (J. G. Fraser \& J. L. Mangan, unpublished results). Leaves contained some five times as much lipid as did the petioles. No correlation was found between crude lipid content, or any of its major fractions, and the occurrence of bloat.

Lipid release during chewing. In a preliminary study of the release of various substances during chewing, it was found that only $20-30 \%$ of the chlorophyll was released as against $50-60 \%$ of polyphenol (J. W. Lyttleton, J. L. Mangan \& C. S. W. Reid, in preparation). Cytoplasmic protein was released to about the same extent as polyphenol (J. L. Mangan, unpublished work).

Since the greater part of the plant fat is concentrated in the chloroplasts, these results are interpreted as indicating that chewing releases lipids less efficiently than it does water-soluble materials.

Rumen contents. Detectable anti-foaming activity is present in rumen contents. Crude rumen liquor will foam only poorly in vitro and must be freed of suspended material, particularly chloroplasts, to reveal its full foaming potential (Mangan, 1959). The contribution of lipids to this activity will depend on both the duration of their stay in the rumen and their 'availability'.

The tendency of free oils and melted fats to float and concentrate at the surface of the rumen contents probably facilitates their early transference to the omasum. Certainly both glycerides and paraffin oils, given either by mouth or through a fistula, appear to be lost from the rumen quite rapidly. However, plant fats associated with chloroplasts are dispersed through the rumen contents rather like an emulsion, and the rate of loss is probably more akin to that of water-soluble materials.

Removal by the micro-organisms may well represent a major drain on 'available' lipid. An oligotrich, Epidinium ecaudatum Crawley, which was normally engorged 18 (2) 4 
with chloroplasts and apparently digested them was found in large numbers in the rumens of cows given red clover (Oxford, 1958).

That the activity of the micro-organisms does affect the anti-foaming activity of rumen contents was shown by the marked increase in anti-foaming activity after small oral doses of penicillin (Johns, Mangan \& Reid, 1957). The mechanism of this effect was not discovered. The foaming potential of rumen liquor was also increased by the treatment, presumably as a result of the temporary accumulation of protein consequent on the slower fermentation.

Whether or not the processes of breakdown and transformation of glyceride fats occurring in the rumen (Shorland, Weenink \& Johns, I955) affect anti-foaming activity is not clear. Both the original and the modified fatty acids are good antifoaming agents, but they may not be fully 'available'.

These isolated observations are too limited to allow any conclusions to be drawn as to the role of dietary anti-foaming agents in the occurrence of bloat. Rather, they serve merely to show how complex the situation is likely to be. It may be speculated that temporary changes in the proportions of foaming to anti-foaming agents, brought about by their different rates of release during chewing, could be important. However, this possibility cannot be assessed without knowledge of the normal patterns of change in anti-foaming activity in the rumen. Systematic investigation of these patterns, particularly of the part played by micro-organisms, is much needed.

That anti-foaming agents should be so effective in preventing bloat strongly supports the foam theory of its cause. However, it must be admitted that, beyond the simple concept of foam-breaking, at the moment we have little idea of how or why they work.

\section{REFERENCES}

Brown, L. R., Johnson, R. H., Jacobson, N. L. \& Homeyer, P. G. (1958). F. Anim. Sci. 17, 374. Campbell, I. L. \& Munford, R. E. (1957). Proc. N.Z. Soc. Anim. Prod. 17, 25.

Cole, H. H., Dougherty, R. W., Huffman, C. F., Hungate, R. E., Kleiber, M. \& Maclay, W. D. (I956). Publ. nat. Res. Coun., Wash., no. 388, revised.

Flynn, K. E. (1958). Dairy Fmg Dig. 4, no. 5, p. 2.

Johns, A. T. (1954). N.Z. F. Sci. Tech. 36, sect. A, p. 289.

Johns, A. T. (1956). Vet. Rev. Annot. 2, 107.

Johns, A. T. (1958). Vet. Rev. Annot. 4, 17.

Johns, A. T., Mangan, J. L. \& Reid, C. S. W. (I957). N.Z. vet. F. 5, II 5.

Leitch, I. \& Thomson, J. S. (1944-5). Nutr. Abstr. Rev. 14, 197.

McDowall, F. H., McGillivray, W. A. \& Reid, C. S. W. (1957). N.Z. F. Sci. Tech. 38, sect. A, p. 839. McDowall, F. H., Patchell, M. R. \& Reid, C. S. W. (1957). N.Z. F. Sci. Tech. 38, sect. A, p. I036. McDowall, F. H., Reid, C. S. W. \& Patchell, M. R. (1957). N.Z. J. Sci. Tech. 38, sect. A, p. Io54. McGillivray, W. A. (1957). N.Z.F. Sci. Tech. 38, sect. A, p. 878 .

McGillivray, W. A., McDowall, F. H. \& Reid, C. S. W. (1959). N.Z, J. agric. Res, 2, 35

Mangan, J. L. (1959). N.Z.F. agric. Res. 2, 47.

Oxford, A. E. (1958). N.Z. F. agric. Res. I, 809.

Reid, C. S. W. (1955). Proc. N.Z. Grassl. Ass. I7th Conf. p. 70.

Reid, C. S. W. (1957). N.Z. F. Sci. Tech. 38, sect. A, p. 825.

Reid, C. S. W. (1958). N.Z.F. agric. Res. I, 349 .

Reid, C. S. W. \& Hutchings, H. E. (I959). N.Z. F. agric. Res. 2, 26.

Reid, C. S. W. \& Johns, A. T. (1957). N.Z. F. Sci. Tech. 38, sect. A, p. 908.

Shorland, F. B., Weenink, R. O. \& Johns, A. T. (1955). Nature, Lond., 175, I129.

Southcott, W. H. \& Hewetson, R. W. (1958). Aust. vet. F. 34, 136.

Winchester, C. F. \& Morris, M. J. (1956). J. Anim. Sci. 15, 722. 